\title{
Impact Of Sales Growth And Company Size Towards Financial Structure
}

\author{
Danna Solihin ${ }^{1}$, Adisthy Shabrina Nurqamarani ${ }^{2}$ \\ ${ }^{* 1}$ Faculty of Economic, University 17 Agustus 1945 Samarinda, ${ }^{2}$ Universitas Terbuka \\ Email : solihindanna@gmail.com
}

\begin{abstract}
The research examines impacts of sales growth and company size to financial structure. Research conducted at firms in mining industries which go public in Indonesia Stock Exchange. Data were analyzed using multiple regression analysis. The results of the research show that the sales growth and company size positively affect the firms' financial structure in the mining sector listed on the Indonesia Stock Exchange. Sales growth variable has significant effect while company size has no significant effect to financial structure. Furthermore, during the last three years between 2013-2015, sales growth and the company size of mining sector companies continue to decline. This is due to the decline in world coal prices followed by slowing demand for coal and crude oil. Consequently, policy makers and managers of mining industries should consider sales growth and company size in arranging the company financial structure. They can use based on these findings, especially more attention on sales growth to manage that financial structure.
\end{abstract}

Keywords: Sales growth, company size and financial structure.

\section{INTRODUCTION}

The mining sector has been one of the key sectors supporting Indonesia's economic growth as it makes a significant contribution to Indonesian GDP, exports, government revenues, employment, as well as the economic development of the remote regions where mining operations are located (SES Professionals, 2018).

However, inadequate supporting infrastructure (such as power, rail, roads and ports) to support downstream processing facilities in many areas of the country may not be economically feasible in some cases. At the same time, the ban on export of unprocessed ores means that cash flows may not be available to support investment in downstream processing.

Many investors view Indonesia as having significant geological potential in terms of its coal resources, but the regulatory uncertainties and, to a certain extent, the royalty and fiscal regimes have become key deterrents to investment ( $\mathrm{PwC}, 2018)$. This becomes challenges in this low commodity price environment when mining companies are looking to improve operating efficiency and productivity and are limiting capital spending.

Mining industry has several characteristics which differentiates it with other industries. It has high barrier to entry as it requires high capital investment to enter. Moreover, it also has high threat of substitutes since mining industry negatively perceived by local citizens contributed negatively to environment. Therefore, high barrier to entry and threat of substitutes in mining industry demands firms to strive to maintain its survival by adjusting to changes in economic environment conditions.

Changes in the economic environment have significant impacts on the business environment, and not all sectors are able to survive in changing conditions of the economic environment. Many companies do various ways to expand their business, and certainly not a small amount of funds required by the company to develop and run the business activities of the company.

Funding sources earned by a company generated from internal funds as well as external funds. Internal fund sources represent funds obtained from the results of the operations of the company consisting of retained earnings and depreciation. External sources of funds are sources of funds obtained from outside the company consisting of suppliers, banks, and capital markets (Riyanto, 2011). 
The funding patterns of an enterprise will determine the best financial structure. Weston and Copeland (1997) mention several factors that affect the company's financial structure that is the level of sales growth, cash flow stability, industry characteristics, asset structure, management attitude and lender attitude.

Supriyanto \& Falikhatun (2008) investigated the impact of tangibility, firm size, and sales growth on financial structures at Food \& Beverage sector in Indonesia. The result showed that tangibility, firm size, and sales growth influenced firms' financial structures. Kusuma and Roekhudin (2004) analyzed impact of asset structure, sales growth, operating leverage, return on investment and firm size on the financial structure of plastics companies going public on the Jakarta Stock Exchange (BEJ). The results showed that asset structure, return on investment and firm size has an influence on financial structure. Prayudi et al. (2004) tested the variables affecting the financial structure of the metal industry in Indonesia. The results showed that firm size, return on investment (ROI) and financial leverage affect the financial structure.

Firm size and sales growth are constructs of scholarly interest since they traditionally have much explanatory power, and an understanding of their importance can be vital for managers who operate in today's competitive environments. This study re-examined the results of previous research by modifying the research object referring to Supriyanto \& Falikhatun's research (2008), using the mining industry's object and a period of time from 2013 to 2015 . Therefore, the formulation of the problem to be tested is whether sales growth and firm size have an influence on the financial structure of mining companies that go public in Indonesia Stock Exchange (BEJ).

\section{THEORETICAL REVIEWS}

\section{Human Capital Model}

This theory was developed by Doeringer and Piore (1971). The human capital model, in which earnings reflect skill differentials in perfect factor markets, has dominated the interpretation of earnings functions. The finding that earnings raise with firm size has been widely interpreted in this framework. The human capital explanation is that the vector of relevant productive skills is partially unobserved, and that the significance of firm characteristics in earnings regressions essentially reflects un-observed labor quality. This is under the assumption that large firms hire more able individuals than do small firms. This model illustrates that firm size is positively correlated with earnings and is entirely consistent with competitive labor markets. It is therefore indicative that as a firm grows in size, it is able to attract efficient workers and develop its human capital for better performance (Kioko, 2010).

\section{Theory of Growth of the Firm}

This theory was founded by Penrose (1959) who offered durable principles governing the growth of firms and the rate at which firms can grow efficiently and be profitable. Penrose (1959) provides at least three key arguments concerning linkages among firm's resources, productive opportunities, and profitable firm growth. Penrose (1959) first maintains that firms can create economic value not due to mere possession of resources, but due to effective and innovative management of resources. This indicates that a firm commanding massive resources is not necessarily more profitable than firm commanding little resources. Creative resource deployments spur differences in productive opportunities and financial performance. Penrose (1959) also provides causal links 
between resources and the generation of productive opportunities for growth and innovation.

In the spirit of dynamic capabilities, new combinations of resources lead to innovation and economic value creation. Large firms are expected to have this more than small firms. Penrose (1959) explains the drivers of the rate and direction of firm growth. The availability of top managerial and technical talent serves as the bottleneck for a firm's growth rate in a particular period of time. The current knowledge bases and underutilized resources of the firm determine the direction of firm growth. Penrose (1959) provides a comprehensive explanation of the link between resource-based relatedness and firm level performance. Firms that command huge resources and attract the best management are therefore expected to perform better than their peers according to the growth of the firm theory.

\section{Economic Theory}

Economic theory suggests that increasing firm size allows for incremental advantages because the firm size enables it to raise the barriers of entry to potential entrants and to gain leverage on the economies of scale to attain higher profitability. In the case of banking sector in Kenya, a new entrant has to suffer substantial fixed costs in gaining entry to the industry through acquiring and maintaining set capital requirements and investments as well as advertising extensively to let customers know that it is in the market (Kioko, 2010). This means that the higher the barrier to entry, the threat of potential competition will be lower, which leads to higher profits (Chrystal \& Lipsey, 1997).

The size of a firm affects performance in many ways. Key features of a large firm are its diverse capabilities, the abilities to exploit economies of scale and scope and the formalization of procedures. These characteristics, by making the implementation of operations more effective, allow larger firms to generate superior performance relative to smaller firms (Amato and Wilder, 1990).

Industrial organization economists point to industry effects using the structure-conductperformance model (SCP) as the main factor determining firm profitability (Porter, 1998). On the other hand, the resource-based view (Barney, 1991) suggests that the explanation for the existence of more or less profitable firms within the same industry must be found in the internal factors of each company (for example, market share, firm size, skill level, etc.). These firm-specific factors favor the achievement and maintenance of competitive advantages of each firm, which eventually lead to different profitability levels among firms belonging to the same industry (Kioko, 2010).

\section{The Pecking Order Theory}

The pecking order theory is one of the most influential theories of corporate finance. The pecking order theory assumes that there is no target capital structure. The firms choose capitals according to the following preference order: internal finance, debt, equity (Chen, 2010).

The pecking order theory expects a positive relationship between growth and leverage, because this theory implies that firms issue equity when their market performance is high (Halfers, 2012). Besides, if the profitability remains fixed and the number of investments increases, the company needs more debt over time to finance these new projects.

Halfers (2012) expected that the growth rate and the leverage ratio are positively correlated with each other, because a firm with a high growth rate could afford a greater financial leverage. 


\section{Firm Size}

The OECD (2005) classification defined SMEs as firms who employ between 10 and 250 employees. Firms with less than 10 employees are micro firms and those with more than 250 are large firms. The OECD notes that this definition may vary by country. In the US, for example, the upper limit is set at 500 employees instead of 250. Micro-sized companies are also often defined to have up to 49 employees and hence SMEs to have between 50 and 249 employees.

Differing to US, The European Union (EU) uses financial data to define size bands instead of number of employees. Firms with turnover between over EUR 2 million and EUR 50 million are classified as SMEs. Firms with less than EUR 2 million in turnover are micro companies and firms with more than EUR 50 million are large firms (Supriyanto \& Falikhatun, 2008).

Another critical element in the classification of firm size categories is the ownership structure of firms. It is necessary to treat subsidiaries of large companies that fall into the micro firm or SME categories according to their turnover or number of employees differently from independent micro firms or SMEs. This study analyzed the effect of firm size and sales growth on financial structure at coal mining industry.

\section{Sales Growth}

The rate of sales growth is a measure of the extent to which the earnings per share of a firm can be increased by leverage (Supriyanto \& Falikhatun, 2008). If sales and profits increase annually, then financing with debt with a fixed expense will increase shareholder income (Weston and Copeland, 1997).

According to Sartono (2001), companies with relatively stable sales mean having cash flow that is also relatively stable; it can use a larger debt than a company whose sales are unstable. In other words, the higher the growth rates of the company's sales the greater the use of loan capital.

According to Pandey (2001), companies whose sales are growing rapidly will need to add to their fixed assets, so that high growth firms will cause companies to seek larger funds.

\section{Financial Structures}

The financial structure is the way companies finance their assets (Weston and Copeland 1997: 19). Structures can be worn all over the right side. In the financial structure there is an important concept that is the leverage factor which is the ratio between the overall book value to the total. $30 \%$ leverage factor means the company uses loan capital of $30 \%$ of the total assets of the company. One aspect to be accounted for is the enormous leverage factor (interest) that should make the creditor a small part of the common stock earnings (Gitosudarmo, 1989).

The increased use of debt in the financial structure, in addition to eliminating the share of common shareholders, will also be fatal to the company, namely the emergence of financial distress. According to Kusuma and Roekhudin (2004) financial distress is a condition used for bankruptcy.

Riyanto (1997) mentioned the rules of financial structure include conservative rules vertical and horizontal conservative. The vertical conservative rules provide a balance limit to be maintained by a firm about the amount of foreign capital with its own capital, while the horizontal conservative rules provide a balance between the amount of its own capital and the amount of fixed assets plus the net inventory.

The entire fixed assets plus the net inventory must be fully closed or purchased with own 
capital i.e. capital that remains embedded within the company.

The amount of capital should not be lesser than the amount of fixed assets plus net inventories.

Rajan and Zingles (1995) investigated the factors that determine capital structure by analyzing funding decisions on public companies in developed countries. The results showed that there are four important variables that affect the company's financial structure include growth, tangibility, profitability and size. Thus, the condition which is considered normal by the rule is a condition that shows the amount of capital itself is equal to the amount of assets plus net inventory

\section{Impacts of Firm Size on Financial Structure}

Organizational size effects have been the focus of many prior studies. The benefits of organizational size may accrue to the financial performance of the organization. Larger organizations seem able to generate stronger competitive capability than their smaller rivals as a result of their superior access to resources, greater market power, and economies of scale and scope (Glen et al, 2003). However, organizational size effects are mixed, since some studies confirm them (e.g. Tarawneh, 2006; Sarkaria and Shergill, 2000), while others find either mixed effects or no effects at all (e.g. Goddard et al, 2006; Mariuzzo et al, 2003).

Discussions of the role of firm size in explaining firm structure have been ongoing in the fields of business accounting. Early research, Sartono (2001) found that big companies who are wellestablished will gain capital easily in capital market compared to small companies. This is supported by Supriyanto \& Falikhatun (2008) who researched the impact of firm size affected to the financial structure. Therefore, the bigger the size of a company, then the bigger possibility the company utilizes the debt and gaining capital which resulted on increase towards financial structure. This finding is coherent with Pandey (2001), Kusuma \& Roekhuding (2004) and Supriyatul and Falikhatun (2005). Liargovas and Skandalis, 2008; Merikas et al, 2006) also support positive relationship between firm size and profitability.

However, Prasetyantoko and Parmono (2008) pointed out, many of these studies neglect the possible effects of other factors, such as market structure, entry barriers and firm strategies. More recent studies have attempted to control for these market and firm-specific characteristics and found more equivocal support for a relationship between firm size and profitability. For instance, Tarawneh (2006) find a firm's market share instead of its size plays a 5 significant role in explaining its relative performance. Amato and Amato (2004) find evidence in US retailing industries to support Porter's (1998) conjecture that both small and large firms can effectively capture niche markets, while middlesized firms are 'stuck in the middle' in the sense that they are less competitive than their counterparts in either end of the firm size distribution.

Wafula (2009) tested the drivers of return for the firms listed on the Nairobi stock exchange. The data collected covered the period covering 2002 December to 2008 December. The focus was to come up with the geometric stock returns on the stock prices for each year. The independent variables which were used in the research were the book to market, cash flow ratio, the dividend yield, firm size and the profitability ratio. The conclusion drawn from the research was that in Kenya, stock returns are weakly driven by the firm specific factors. The study found a weak positive relationship between firm size and return for the firms under study.

Whittington (1980) even found a negative association between firm size and profitability for 
U.K. based listed manufacturing companies covering the time period from 1960 to 1974 . While no suitable reasoning can be used to explain such a link, organizational theory may perhaps solve part of this quandary. Further, it has been suggested that increased size tends to be associated with higher bureaucratization (Liargovas \& Skandalis, 2008). Larger firms may have overly bureaucratic management structures, thereby inhibiting swift and efficient decision-making process. Kioko (2010) stated that with the additional management layers needed to organize an increasingly large and diverse workforce, management may be affected by the agency problems. Therefore, this following hypothesis is proposed:

$H_{l}$ : Firm size influences the financial structures on firms in mining industries who go public in Indonesia Stock Exchange.

\section{Impacts of Sales Growth on Financial Structure}

Supriyanto \& Falikhatun (2008) found that sales growth affected financial structure which proved through positive coefficient regression value. This means that changes in sales growth will affect changes in financial structure. Sartono (2011) mentioned that firms with stable sales means having streamlined financial, which can utilize bigger debt. This supported Pandey (2011) as well as Kusuma \& Roekhudin (2004). The faster the sales growth of firms, the higher investment needed to finance the expansion.

Noulas and Genimakis (2011) found significant positive correlations

Between firm's leverage and sales, growth rate, tangibility of assets, depreciation, profit volatility and credit rating. Therefore, this following hypothesis is proposed:

$\mathrm{H}_{2}$ : Sales growth influences the financial structures on firms in mining industries who go public in Indonesia Stock Exchange.

\section{RESEARCH METHODOLOGY}

The research method used in this research is descriptive explanatory research method. The research was conducted on the mining sector in Indonesia Stock Exchange. The data used are financial reports published by Indonesia Stock Exchange period 2013-2015. The sample used is mining company which publishes its financial report continuously period 2013-2015 (31 companies). The variables used are Sales Growth (X1), Company Size (X2) and Financial Structure (Y). Definitions of each variable are:

a. Sales Growth

Sales growth is the ratio between the change (increase or decrease) of the final year sales against the initial year. According Kesuma (2009) formula to calculate sales growth:

$$
\text { Sales Growth }=\frac{S \quad{ }_{L}-S \quad L-1}{S \quad[-1} \times 100 \%
$$

\section{b. Company Size}

The company size is the size of a company by looking at the value of equity, sales value or total assets (financial ability) owned by a company. According Riyanto (2011) the formula to calculate the size of the company: 
Company Size $=$ Ln $($ Total Asset $)$

c. Financial structure

The financial structure is how the company finances its assets. According to Supriyanto and Falikhatun (2008), the formula for calculating the financial structure is:

$$
\text { Financial Structure }=\frac{T}{T} \frac{D}{A} \times 100 \%
$$

Analysis techniques used to test the hypothesis is multiple linear regression, the models:

$\mathrm{Y}=\mathrm{a}+\beta_{1} \mathrm{X}_{1}+\beta_{2} \mathrm{X}_{2}+\mathrm{e}$

Note: $\mathrm{Y}=$ Financial Structure; $\mathrm{X}_{1}=$ Sales Growth; $\mathrm{X}_{2}=$ Company Size; $\mathrm{e}=$ error term.

\section{ANALYSIS}

Tests using multiple linear regression analysis, obtained the following results:

Table 1: results of hypothesis

\begin{tabular}{|l|l|l|l|}
\hline \multirow{2}{*}{ Model } & \multicolumn{2}{|c|}{} \\
\cline { 2 - 4 } & B & t-count & Significant-t \\
\hline $\begin{array}{l}\text { (Constant) } \\
\text { Sales Growth }\end{array}$ & 293,635 & & \\
\hline Company Size & .0132 & 3,294 & .001 \\
\hline
\end{tabular}

a. Dependent Variable: Financial Structure

Based on the test results, it can be entered into the model as follows:

$\mathrm{Y}=293,635+0,332+0,018+\mathrm{e}$

From the regression equation can be described as follows:

1. Constant

The value of the constant of this regression equation is positive. Value $B=293,635$ indicates that if there is no variable growth of sales and company size accordingly financial structure value equal to 293,635 .

2. Regression coefficient of sales growth

Sales growth has a positive and significant impact on the financial structure, it can be seen from the significant value of 0.001 . The coefficient value for the sales growth variable is 0.332 . A positive sign indicates that sales growth has a direct effect with the financial structure. These results indicate that if other variables are considered constant, changes in sales growth of $1 \%$ will give a direct effect of $0.332 \%$.

3. Regression coefficient of company size

The company size has a positive and insignificant effect on the financial structure; it can be seen from the significant value of 0.859 . The coefficient value for the company size variable is 0.018 . The positive sign indicates that company size has a direct effect with the financial structure. These 
results indicate that if other variables are considered constant, a $1 \%$ change in firm size will have a direct effect of $0.0178 \%$.

Table 2: Sales Growth

\begin{tabular}{|l|c|c|c|c|}
\hline \multirow{2}{*}{\multicolumn{1}{|c|}{ Note }} & \multicolumn{3}{|c|}{ Year } & \\
\cline { 2 - 5 } & $\mathbf{2 0 1 3}$ & $\mathbf{2 0 1 4}$ & $\mathbf{2 0 1 5}$ & $\mathbf{2 0 1 3 - 2 0 1 5}$ \\
\hline Highest & 400,79 & 259,79 & 222,07 & 400,79 \\
\hline Lowest & $-77,95$ & $-100,00$ & $-74,09$ & $-100,00$ \\
\hline Average & 10,66 & $-18,25$ & $-4,95$ & $-4,18$ \\
\hline
\end{tabular}

source: data processed

Based on the results of the research, it showed that in general the average growth of sales of mining companies from 2013 to 2015 is equal to the average range of -100 to 400.79 . In the past three years there has been a significant decline in sales, especially in 2014, where sales decline reached -100 level. This is due to the slowdown in global economic growth resulting in lower demand for commodities such as coal. In addition, the Indonesian Government's Coal Reference Price (HBA) declined by $27 \%$ in 2014 . The decline in world coal prices is due to excess supply and excess capacity in the market.

Table 3: Company Size

\begin{tabular}{|l|c|c|c|c|}
\hline \multirow{2}{*}{ Note } & \multicolumn{3}{|c|}{ Year } \\
\cline { 2 - 5 } & $\mathbf{2 0 1 3}$ & $\mathbf{2 0 1 4}$ & $\mathbf{2 0 1 5}$ & $\mathbf{2 0 1 3 - 2 0 1 5}$ \\
\hline Highest & 1219,80 & 1224,89 & 1238,90 & 1238,90 \\
\hline Lowest & 570,69 & 567,00 & 562,88 & 562,88 \\
\hline Average & 908,65 & 891,99 & 890,65 & 897,097 \\
\hline
\end{tabular}

Source: data processed

Based on the results of this study, it is seen that every year within three years, the size of the mining sector companies continued to decline. This is as a result of the decline in world coal prices that cause mining companies to strive to increase productivity, such as struggling to survive followed by asset sales or business closure.

Table 4: Financial Structure

\begin{tabular}{|l|c|c|c|c|}
\hline \multirow{2}{*}{ Note } & \multicolumn{4}{|c|}{ Year } \\
\cline { 2 - 5 } \multicolumn{1}{|c|}{$\mathbf{2 0 1 3}$} & $\mathbf{2 0 1 4}$ & $\mathbf{2 0 1 5}$ & $\mathbf{2 0 1 3 - 2 0 1 5}$ \\
\hline Highest & 8902,32 & 4755,38 & 3479,50 & 3479,50 \\
\hline Lowest & 0,756402 & 1,67 & 4,13 & 0,756402 \\
\hline Average & 354,41 & 194,79 & 151,38 & 233,5241 \\
\hline
\end{tabular}

Source: data processed

Based on the results of this study, it is seen that the financial structure of the company continues to decline every year within three years. The decline in sales growth and firm size in the mining sector directly affected the financial structure decline in the sector. 


\section{DISCUSSIONS}

Sales growth affects the financial structure. These results are supported by Brigham and Houston (2001) in Hany, et al (2014) that influential factors in the financial structure include stability of sales, growth rates, market conditions and financial flexibility.

The company size affects the financial structure. The results are supported by Sartono (2001) in Supriyanto and Falikhatun (2008) that large well-established companies will be easier to obtain capital in the capital market than small company, so the larger size of company, more the company's tendency to use more debt and lead to an increase in the company's financial structure.

\section{CONCULUSION, LIMITATIONS, AND RECOMMENDATIONS}

Based on the results of this study, it can be concluded that the sales growth and company size positively affect the financial structure in the mining sector listed on the Indonesia Stock Exchange. Sales growth variable has significant effect while company size has no significant effect to financial structure. Furthermore, during the last three years between 2013-2015, sales growth and the company size of mining sector companies continue to decline. This is due to the decline in world coal prices followed by slowing demand for coal and crude oil.

There are several limitations of this research, first, it merely used two independent variables that affect the company's financial structure while there are still a lot of factors which may influence the firms' financial structure. Second, the period of research for three years (2013-2015) which is considered as a period of crisis in the mining sector. This means that this research does not reflect or distinguish the research results when the economic condition of Indonesia is down, up, stable, or grow.

In order to obtain better research results, the researchers recommend the next research should add more variables affecting the firms' financial structure include variables of cash flow stability, management attitude, and lender attitude. Furthermore, the researchers also suggest the next research to conduct research based on more recent data in longer time span in order to evaluate the effect when the economic condition of Indonesia is down, up, stable, or grow.

\section{REFERENCES}

Amato, L. and Wilder, R. P. (1990). Firm and industry effects in industrial economics. Southern Economic Journal, 50, 93-105.

Amato, L. J. and Amato, C. H. (2004). Firm size, strategic advantage, and profit rates in US retailing. Journal of Retailing and Consumer Services, 11(3), 181-193.

Barney, J. (1991). Firm resources and sustained competitive advantage. Journal of Management, 17, 99-120.

Chen, L. (2010). How The Pecking Order Theory Explain Capital Structure [online]. Available from https://pdfs.semanticscholar.org/4778/e51d44c1adf7bb50562c07d4bacd6d0494e5.pdf [Accessed on 7 May 2018]

Chrystal, K.A., Lipsey, R.G., 1997. Economics for Business and Management. Oxford University Press, Oxford.

Doeringer, P. \& Piore, M. 1971. Internal Labor Markets and Manpower Analysis, Lexington: Mass.

Gitosudarmo, I. 1989. Manajemen Keuangan. Yogyakarta: BPFE.

Glen, J., Lee, K. and Singh, A. 2003. Corporate profitability and the dynamics of competition in emerging markets: A time series analysis. Economic Journal, 113 (491), pp.465-484. 
Goddard, J., Tavakoli M. and Wilson, J. O. S. 2005. Determinants of profitability in European Manufacturing and services: evidence from a dynamic panel model. Applied Financial Economics, 15 (18), pp.1269-1282.

Halfers, R.J.E. 2012. The determinants of firms' capital structure decisions in North America between 2001 and 2010. Netherland: Universiteit Van Tilburg.

Hani, S. \& Rahmi, D.A. 2014. Analisis Pertumbuhan Penjualan dan Struktur Aktiva Terhadap Struktur Pendanaan Eksternal. Jurnal Manajemen \& Bisnis Vol.14 No.01 April 2014

Kesuma, A. 2009. Analisis Faktor Yang Mempengaruhi Struktur Modal Serta Pengaruhnya Terhadap Harga Saham Perusahaan Real Estate yang Go- Public di Bursa Efek Indonesia. Jurnal Manajemen dan Kewirausahaan.

Kioko, N.P. 2010. The Relationship Between Firm Size and Financial Performance Of Commercial Banks In Kenya. Kenya: University of Nairobi

Kusuma, D. \& Roekhudin. (2004). Analisis Pengaruh Struktur Aktiva, Pertumbuhan Penjualan, Operating Leverage, Return on Investment, Dan Ukuran Perusahaan Terhadap Struktur Keuangan Pada Perusahaan Plastik Yang Go Public Di BEJ. Skripsi. Malang: Universitas Brawijaya.

Liargovas, P. and Skandalis, K. (2008). Factors affecting firm's financial performance: the Case of Greece, University of Peloponnese.

Mariuzzo, F., Walsh, P. and Whelan, C. (2003). Firm size and market power in carbonated soft drinks, Review of Industrial Organization, 23(4), 283-299.

Merikas, G., Merika, A. and Skandalis, S. (2006). An effective index of management competence. Paper presented at the 15th Annual Conference of European Financial Management Association-EFMA, Madrid.

Organization for Economic Cooperation and Development. (2005). OECD Principles of Corporate Governance 2005. The OECD Paris.

Pandey, I.M. (2001). Capital Structure and The Firm Characteristics: Evidence from An Emerging Market. IIMA, Working Paper.

Penrose, E. T. (1959). The Theory of the Growth of the Firm. New York: John Wiley.

Porter, M.E. (1998). Competitive strategy: Techniques for analyzing industries and competitors. New York: Free Press.

Prasetyantoko, A. and Parmono, R. 2008. A Comparison of Financial Performance in the Banking Sector: Some Evidence from Omani Commercial Banks. International Research Journal of Finance and Economics, 3, 1-22.

Prayudi, Herman. Moeljadi, P. and Atim D. (2004). Analisis Variabel-Variabel Yang Mempengaruhi Struktur Keuangan Pada Perusahaan Industri Logam Yang Go Public di Indonesia. Skripsi. Malang: Universitas Brawijaya.

PwC. (2018). Mining in Indonesia. Investment and Taxation Guide May 2016 - 8th edition [online]. Available from https://www.pwc.com/id/en/energy-utilitiesmining/assets/May\%202016/PwC\%20Indonesia-mining-in-Indonesia-survey-2016.pdf [Accessed on 10 May 2018]

Rajan, R.G. \& Zingles, L. (1995). What do we know about capital structure? Some evidence from international data. Journal of finance, Vol.50, 5, pp.1421-1460.

Riyanto, Bambang. (1997). Dasar-Dasar Pembelanjaan Perusahaan. Edisi Kedua. Yogyakarta: 
BPFE.

Riyanto, B. (2011). Dasar-Dasar Pembelanjaan Perusahaan. Yogyakarta: BPFE

Sarkaria, M. and Shergill, G. S. (2000). Market structure and financial performance - An Indian evidence with enhanced controls. Indian Economic Journal, 48(2), pp 98-105.

Sartono, Agus R. (2001). Manajemen Keuangan. Edisi 3. Yogyakarta: BPFE.

SES Professionals. (2018). Overview of Indonesia's Mining Industry [online]. Available from http://sesprofessionals.com/overview-of-indonesias-mining-industry/ [Accessed on 10 May 2018]

Supriyanto, E. \& Falikhatun. (2008). Pengaruh Tangibility, Pertumbuhan Penjualan dan Ukuran Perusahaan Terhadap Struktur Keuangan. Jurnal Bisnis dan Akuntansi, Vol.10, No. 1, April 2008, 13-22.

Tarawneh, M. (2006). A comparison of financial performance in the banking sector: Some Evidence from Omani Commercial Banks. International Research Journal of Finance and Economics, 3, 25-36.

Wafula, E. (2009). The Drivers Of Return For Firms Listed On The Nairobi Stock Exchange. An unpublished MBA project, University of Nairobi.

Weston, J. F. \& Brigham U. F. (1994). Dasar-Dasar Manajemen Keuangan. Edisi Ketujuh. Jilid 2.Jakarta: Erlangga.

Weston, J.F. \& Copeland, T.E. (1997). Manajemen Keuangan. Edisi Kesembilan. Jilid 2. Jakarta: Binarupa Aksara.

Whittington, G. (1980). "Positive Accounting: A Review Article." Accounting and Business Research. 17. 68. pp. $327-336$ 